\title{
Fractional Excretion of Uric Acid as a Predictor for Saline Responsiveness in Long-Term Kidney Transplant Patients
}

\author{
Jong-Wook Choi Joon-Sung Park Tai Yeon Koo Chang Hwa Lee \\ Chong Myung Kang Gheun-Ho Kim \\ Department of Internal Medicine, Hanyang University College of Medicine, Seoul, South Korea
}

\section{Key Words}

Acute kidney injury $\cdot$ Kidney transplantation $\cdot$ Tubular transport · Uric acid

\begin{abstract}
Background/Aims: Subclinical hypovolemia may contribute to allograft dysfunction in long-term kidney transplant (KT) patients. In order to predict responsiveness to saline hydration, indices for tubular transport were investigated. Methods: Fifty-four clinically euvolemic long-term KT patients with recently aggravated azotemia were given intravenous hydration as follows: $0.9 \%$ saline $5 \mathrm{ml} / \mathrm{kg}$ over $1 \mathrm{~h}$, followed by $0.9 \%$ saline $1 \mathrm{ml} / \mathrm{kg} / \mathrm{h}$ over $12 \mathrm{~h}$ and 1 liter of $0.45 \%$ saline over the next $24 \mathrm{~h}$. Serum and urine data were collected and analyzed to assess responses. Results: In all patients, saline hydration relieved azotemia, as shown by blood urea nitrogen (46.9 \pm 17.2 vs. $39.3 \pm 15.4 \mathrm{mg} / \mathrm{dl} ; \mathrm{p}<0.01)$ and serum creatinine levels $(2.9 \pm 1.1$ vs. $2.5 \pm 1.1 \mathrm{mg} / \mathrm{dl} ; \mathrm{p}<0.01)$ on day 0 versus day 2 . In 38 patients, serum creatinine did not increase in the following month (70\% responders). Compared with the nonresponders, the responders had a higher urine-to-plasma creatinine ratio and lower fractional excretion of sodium, uric acid and urea at admission. Multivariate logistic regression analysis revealed that responsiveness to
\end{abstract}

saline hydration was independently associated with lower fractional excretion of uric acid. Conclusion: Subclinical hypovolemia should be considered in long-term KT patients with azotemia of unexplainable causes. Fractional excretion of uric acid may predict responsiveness to saline hydration.

Copyright $\odot 2012$ S. Karger AG, Basel

\section{Introduction}

Kidney transplantation is the optimum treatment for many patients with end-stage renal disease [1]. Although 1 -year transplant survival is excellent [2], most recipients experience chronic renal transplant dysfunction with time. Despite ever-improving immunosuppression, longterm renal allograft survival remains unchanged. Chronic allograft dysfunction in kidney transplant (KT) recipients is a clinically defined condition characterized by a slow, progressive decrease in the glomerular filtration rate, associated with de novo or aggravated hypertension and worsening proteinuria [3].

J.-W.C. and J.-S.P. contributed equally to this work.

\section{KARGER}

Fax +4161306 1234

E-Mail karger@karger.ch

www.karger.com (c) 2012 S. Karger AG, Basel

$1420-4096 / 12 / 0356-0627 \$ 38.00 / 0$

Accessible online at:

www.karger.com/kbr
Gheun-Ho Kim, MD, PhD

Department of Internal Medicine, Hanyang University College of Medicine

17 Haengdang-dong Seongdong-gu

Seoul 133-792 (South Korea)

Tel. +82 22290 8318, E-Mail kimgh@ hanyang.ac.kr 
Most late allograft failure is attributed to chronic allograft nephropathy (CAN), although that is a clinicopathological description not a specific diagnostic entity [4]. Its pathogenesis and treatment are largely unknown, and clinicians are frequently puzzled when they encounter unexplained azotemia in long-term KT patients. CAN is characterized histologically by interstitial fibrosis and tubular atrophy and is variably associated with fibrointimal thickening of the arteries within the transplanted kidney, as originally agreed in the Banff classification of 1997 [5]. This pathology is believed to be associated with tubular dysfunction such as salt wasting and defective urinary concentration.

In addition, sodium and water reabsorption in the proximal tubule may not be stimulated by renal sympathetic nerve activity when the kidney is denervated [6], and denervation of the donor kidney is inevitable in the transplantation procedure. Therefore, we postulated that patients with CAN may have defects in sodium and water conservation. Although volume depletion is a wellknown reversible factor that interferes with renal function, it is difficult to assess volume status from the clinical setting and physical findings. Thus, intravenous fluid challenge is useful to test whether the patient is hypovolemic or not. In this study, intravenous saline was administered to long-term KT patients when their azotemia had been recently aggravated without any identifiable causes. In order to predict responsiveness to saline hydration, we investigated indices for tubular transport in long-term KT patients who are subclinically hypovolemic.

\section{Methods}

\section{Patients}

Patients with KT were enrolled between April 2007 and November 2010 at Hanyang University Hospital in Seoul, Korea. Eligibility criteria were as follows: time since $\mathrm{KT}>1$ year, recently aggravated azotemia (serum creatinine increase $\geq 30 \%$ during the last month), no signs of calcineurin inhibitor toxicity and no evidence of overt hypovolemia (including orthostatic hypotension). Patients were excluded if they were identified as having transplant renal artery stenosis, acute or chronic rejection, overt toxicity, systemic infectious disease, urinary tract obstruction or recurrent or de novo specific disease entities.

\section{Study Protocol}

On admission, all patients received $0.9 \%$ saline intravenously at a rate of $5 \mathrm{ml} / \mathrm{kg}$ over $1 \mathrm{~h}$ immediately after basal blood and urine sampling. This initial hydration was followed by $1 \mathrm{ml} / \mathrm{kg} / \mathrm{h}$ of $0.9 \%$ saline over the next $12 \mathrm{~h}$ and 1 liter of $0.45 \%$ saline over the following $24 \mathrm{~h}$. Other medication including immunosuppressants, antihypertensives and diuretics was maintained.
Table 1. Patient demographics

\begin{tabular}{lc}
\hline Patients & 54 \\
Age, years & $48 \pm 10$ \\
Males & $33(61 \%)$ \\
Time since transplant, months & $145 \pm 57$ \\
Underlying disease & \\
$\quad$ Diabetes mellitus & 2 \\
Hypertension & 13 \\
Chronic glomerulonephritis & 18 \\
Alport syndrome & 1 \\
Unknown & 20 \\
\hline
\end{tabular}

Data are means \pm SDs or number of patients (percentage), as appropriate.

Serum and urine data were collected to examine allograft dysfunction on admission (day 0), day 1 and day 2 and at the 1-month follow-up. Blood urea nitrogen (BUN), serum creatinine, urine creatinine, uric acid and electrolytes were measured using an autoanalyzer (Hitachi 7600-210, Hitachi High-Technologies, Tokyo, Japan). A kinetic Jaffé method was used for creatinine measurement, and enzymatic methods were used to measure urea nitrogen and uric acid. Sodium, potassium and chloride concentrations were determined with ion-selective electrodes. As indices for tubular transport, the urine-to-plasma creatinine ratio (U/ $\left.\mathrm{P}_{\mathrm{Cr}}\right)$ and fractional excretion of sodium $\left(\mathrm{FE}_{\mathrm{Na}}\right)$, uric acid $\left(\mathrm{FE}_{\mathrm{UA}}\right)$ and urea $\left(\mathrm{FE}_{\text {urea }}\right)$ were evaluated. They were calculated from the simultaneously obtained serum and urine samples. Because the goal of the saline hydration was to arrest the progression of azotemia, responders were defined as those whose serum creatinine did not increase in the following month.

\section{Statistical Analysis}

Results are expressed as means \pm SDs or frequencies (and proportions), and data were analyzed with StatView 4.01 (SAS Institute Inc., Cary, N.C., USA). Groups were compared with the Wilcoxon signed-rank test for paired data or the Mann-Whitney $U$ test for unpaired data. Differences were considered statistically significant at $\mathrm{p}<0.05$. Logistic regression was used to model odds ratios (ORs), and 95\% confidence intervals (CIs) were employed as measures of the associations between responsiveness and basal parameters.

\section{Results}

A total of 54 patients completed the study and were included in the final analysis. The average age was $48 \pm 10$ years, and 33 of the patients (61\%) were male. Other demographic characteristics including transplant duration and causes of native kidney disease are shown in table 1 .

Figure 1 illustrates the changes in BUN and serum creatinine levels over the study period. On admission (day 


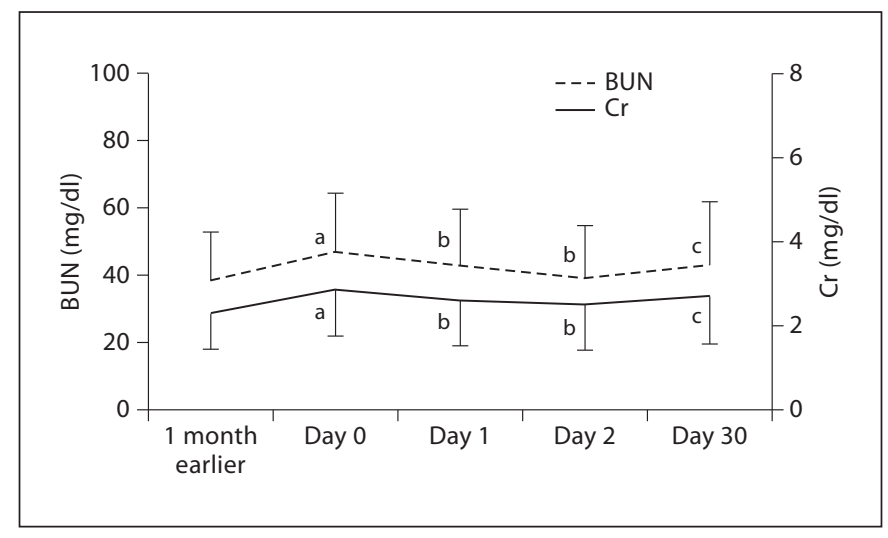

Fig. 1. Changes in BUN and serum creatinine in the total patient population. Comparisons were performed using the Wilcoxon matched-pairs signed-ranks test. ${ }^{a} \mathrm{p}<0.01$ versus 1 month earlier; ${ }^{b} \mathrm{p}<0.01$ versus day $0 ;{ }^{c} \mathrm{p}<0.05$ versus day $0 . \mathrm{Cr}=$ Serum creatinine.

0 ), the patients had significantly higher levels of BUN (46.9 \pm 17.2 vs. $38.6 \pm 14.2 \mathrm{mg} / \mathrm{dl} ; \mathrm{p}<0.01)$ and serum creatinine $(2.9 \pm 1.1$ vs. $2.3 \pm 0.8 \mathrm{mg} / \mathrm{dl} ; \mathrm{p}<0.01)$ than 1 month earlier. After saline hydration, BUN and serum creatinine decreased to $42.9 \pm 17.0 \mathrm{mg} / \mathrm{dl}(\mathrm{p}<0.01)$ and $2.6 \pm 1.1 \mathrm{mg} / \mathrm{dl}(\mathrm{p}<0.01)$, respectively, on day 1 . This beneficial effect was maintained on the following day, with both BUN $(39.3 \pm 15.4 \mathrm{mg} / \mathrm{dl})$ and serum creatinine $(2.5 \pm 1.1 \mathrm{mg} / \mathrm{dl})$ remaining lower than at admission ( $p<0.01$ in each case). Although the relief of azotemia declined, levels of BUN (43.1 $\pm 18.7 \mathrm{mg} / \mathrm{dl})$ and serum creatinine $(2.7 \pm 1.1 \mathrm{mg} / \mathrm{dl})$ on day 30 were still lower than at admission ( $p<0.05$ for each).

However, the outcome on day 30 was not favorable in all patients. In 38 patients (70\%), the serum creatinine level was not higher than at admission, whereas in 16 patients (30\%) it had increased (fig. 2). If the former and the latter were defined as responders and nonresponders, respectively, responders had lower BUN (39.3 \pm 17.3 vs. $52.1 \pm 19.1 \mathrm{mg} / \mathrm{dl} ; \mathrm{p}<0.05)$ and serum creatinine $(2.4 \pm$ 1.0 vs. $3.5 \pm 1.1 \mathrm{mg} / \mathrm{dl} ; \mathrm{p}<0.01)$ than nonresponders on day 30 .

Interestingly, there were no significant differences in BUN and serum creatinine between responders and nonresponders on day 1 (BUN: $43.7 \pm 18.5$ vs. $40.8 \pm 12.8$ $\mathrm{mg} / \mathrm{dl}$; serum creatinine: $2.49 \pm 1.12$ vs. $2.87 \pm 0.92 \mathrm{mg} /$ dl) or day $2(B U N: 39.5 \pm 16.8$ vs. $38.8 \pm 11.5 \mathrm{mg} / \mathrm{dl}$; serum creatinine: $2.35 \pm 1.05$ vs. $2.85 \pm 1.00 \mathrm{mg} / \mathrm{dl}$ ), or even 1 month prior to admission (BUN: $37.8 \pm 15.3$ vs. $40.5 \pm 11.3 \mathrm{mg} / \mathrm{dl}$; serum creatinine: $2.22 \pm 0.88$ vs. 2.50 $\pm 0.66 \mathrm{mg} / \mathrm{dl})$.

Fractional Excretion of Uric Acid in KT Patients

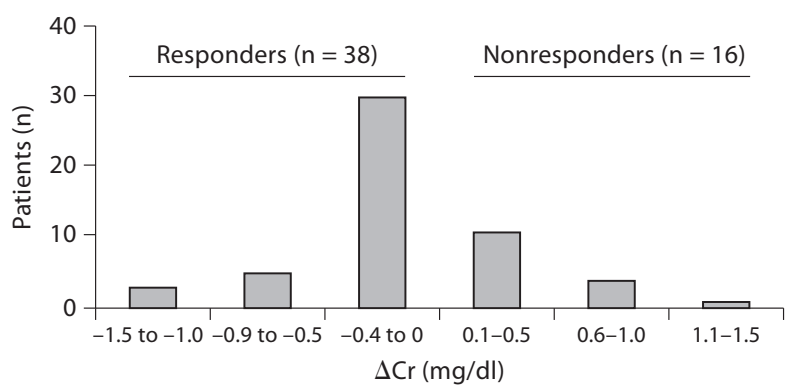

Fig. 2. Distribution of patients by response to saline hydration, measured by the change in serum creatinine as follows: $\Delta \mathrm{Cr}=\mathrm{Se}$ rum creatinine at 1 month - serum creatinine on day 0 .

We compared basal characteristics at admission between responders and nonresponders (tables 2-4). The two groups did not differ significantly with regard to age, gender, body mass index, transplant duration or proportions of immunosuppressant, antihypertensive and diuretic users (table 2). Our patients used small doses of prednisolone at admission, and BUN levels were not significantly different between responders and nonresponders (table 3 ). Interestingly, $\mathrm{FE}_{\mathrm{Na}}$ was not significantly affected by the use of diuretics (diuretic users: $2.4 \pm$ $3.8 \%$; diuretic nonusers: $2.9 \pm 2.6 \%$ ). In contrast, $\mathrm{FE}_{\mathrm{UA}}$ was lower in diuretic users than in diuretic nonusers (10.2 \pm 9.1 vs. $15.4 \pm 10.3 \%$; $\mathrm{p}<0.05)$. $\mathrm{FE}_{\text {urea }}$ was also lower in diuretic users than in nonusers ( $29.7 \pm 14.9$ vs. $46.3 \pm$ $31.2 \% ; \mathrm{p}<0.01)$. $\mathrm{FE}_{\mathrm{UA}}$ was not significantly different between angiotensin receptor blockade users and nonusers (13.4 \pm 7.7 vs. $13.6 \pm 11.5 \%)$.

Whereas BUN and serum creatinine did not differ significantly between the two groups at admission (table 3), serum albumin was higher in the responders than in the nonresponders $(4.12 \pm 0.44$ vs. $3.80 \pm 0.56 \mathrm{~g} / \mathrm{dl}$; $\mathrm{p}<$ $0.05)$. Table 4 presents a comparison of urinary indices at admission in responders and nonresponders. Responders had lower values of $\mathrm{FE}_{\mathrm{Na}}(1.9 \pm 1.8$ vs. $4.3 \pm 4.5 \%$; $\mathrm{p}<$ $0.01), \mathrm{FE}_{\mathrm{UA}}(11.0 \pm 9.0$ vs. $20.1 \pm 10.3 \%$; $\mathrm{p}<0.01)$ and $\mathrm{FE}_{\text {urea }}(33.8 \pm 13.1$ vs. $54.9 \pm 43.0 \%$; $\mathrm{p}<0.05)$ and higher $\mathrm{U} / \mathrm{P}_{\mathrm{Cr}}(41.1 \pm 26.6$ vs. $21.2 \pm 13.8$; $\mathrm{p}<0.01)$ than nonresponders.

In agreement with these findings, some laboratory parameters at admission were associated with responsiveness to saline hydration (table 5). Univariate logistic re- 
Table 2. Comparison of the profiles of responders and nonresponders

\begin{tabular}{lccl}
\hline & Responders $(\mathrm{n}=38)$ & Nonresponders $(\mathrm{n}=16)$ & $\mathrm{p}$ value \\
\hline Age, years & $47 \pm 11$ & $50 \pm 9$ & $\mathrm{NS}$ \\
Males/females & $24 / 14$ & $9 / 7$ & $\mathrm{NS}$ \\
BMI & $23.0 \pm 3.9$ & $22.6 \pm 3.2$ & $\mathrm{NS}$ \\
Diabetics & 2 & 0 & $\mathrm{NS}$ \\
Time since transplant, months & $145 \pm 58$ & $145 \pm 56$ & $\mathrm{NS}$ \\
Medication & & & $\mathrm{NS}$ \\
$\quad$ Prednisolone dose, mg/day & $5.2 \pm 1.2$ & $5.6 \pm 1.4$ & $\mathrm{NS}$ \\
$\quad$ Cyclosporine & $33(87)$ & $15(94)$ & $\mathrm{NS}$ \\
$\quad$ Calcium channel blockers & $29(76)$ & $14(87)$ & $\mathrm{NS}$ \\
$\quad$ Angiotensin receptor blockers & $13(34)$ & $4(25)$ & $\mathrm{NS}$ \\
$\quad$ Diuretics & $14(37)$ & $6(38)$ & \\
\hline
\end{tabular}

Continuous data are presented as means \pm SDs. Other values represent number of patients (percentages). $\mathrm{BMI}=$ Body mass index; NS = not significant.

Table 3. Comparison of blood data at admission in responders and nonresponders

\begin{tabular}{lccc}
\hline & Responders $(\mathrm{n}=38)$ & Nonresponders $(\mathrm{n}=16)$ & $\mathrm{p}$ value \\
\hline BUN, mg/dl & $47.8 \pm 18.8$ & $44.6 \pm 12.7$ & $\mathrm{NS}$ \\
Creatinine, mg/dl & $2.76 \pm 1.13$ & $3.05 \pm 0.93$ & $\mathrm{NS}$ \\
Uric acid, mg/dl & $8.09 \pm 2.08$ & $8.39 \pm 2.22$ & $\mathrm{NS}$ \\
Hemoglobin, g/dl & $10.7 \pm 2.0$ & $10.7 \pm 2.0$ & $\mathrm{NS}$ \\
Protein, g/dl & $6.87 \pm 0.65$ & $6.49 \pm 0.83$ & $\mathrm{NS}$ \\
Albumin, g/dl & $4.12 \pm 0.44$ & $3.80 \pm 0.56$ & $<0.05$ \\
Corrected calcium ${ }^{\mathrm{a}}, \mathrm{mg} / \mathrm{dl}$ & $8.9 \pm 0.5$ & $8.7 \pm 0.9$ & $\mathrm{NS}$ \\
Sodium, $\mathrm{mEq} / \mathrm{l}$ & $137 \pm 5$ & $139 \pm 3$ & $\mathrm{NS}$ \\
Potassium, mEq/l & $4.80 \pm 0.69$ & $4.36 \pm 0.79$ & $\mathrm{NS}$ \\
Chloride, $\mathrm{mEq} / \mathrm{l}$ & $105 \pm 4$ & $106 \pm 4$ & $\mathrm{NS}$ \\
Total CO, $\mathrm{mEq} / \mathrm{l}$ & $19.7 \pm 4.9$ & $21.1 \pm 4.6$ & $\mathrm{NS}$ \\
Anion gap, $\mathrm{mEq} / \mathrm{l}$ & $12.9 \pm 3.1$ & $12.0 \pm 4.4$ & $\mathrm{NS}$ \\
Cystatin C, mg/l & $2.53 \pm 0.77$ & $2.82 \pm 0.93$ & $\mathrm{NS}$ \\
\hline
\end{tabular}

Data are means \pm SDs. NS $=$ Not significant.

${ }^{a}$ Corrected calcium $=0.8 \times(4-$ albumin $)+$ serum calcium.

gression analysis revealed that responsiveness was associated with higher levels of serum albumin (OR 4.016, 95\% CI 1.037-15.55) and U/P $\mathrm{P}_{\mathrm{Cr}}(\mathrm{OR} 1.050,95 \%$ CI 1.009-1.093) and lower levels of $\mathrm{FE}_{\mathrm{Na}}$ (OR 0.755, 95\% CI 0.578-0.985), $\mathrm{FE}_{\mathrm{UA}}$ (OR 0.911, 95\% CI 0.845-0.982) and $\mathrm{FE}_{\text {urea }}(\mathrm{OR}$ $0.941,95 \%$ CI $0.893-0.992)$. However, in multivariate logistic regression analysis, only the association between $\mathrm{FE}_{\mathrm{UA}}$ and responsiveness was significant (OR 0.925, 95\% CI 0.857-0.998). Thus, measurement of $\mathrm{FE}_{\mathrm{UA}}$ could be useful for predicting whether unexplained progressing azotemia would be stabilized by saline hydration.

\section{Discussion}

In spite of all the improvements in immunosuppressive therapy, human leukocyte antigen matching and prevention and careful management of many of the risk factors for CAN, it remains the major cause of renal allograft failure [7, 8]. Allograft function in KT patients is routinely assessed by serum creatinine, urinary sediment analysis and routine biopsy [9]. However, renal tubule function is not usually evaluated in transplant patients, although the extent of tubulointerstitial lesions correlates with 
Table 4. Comparison of urinary indices at admission in responders and nonresponders

\begin{tabular}{lccc}
\hline & Responders $(\mathrm{n}=38)$ & Nonresponders $(\mathrm{n}=16)$ & $\mathrm{p}$ value \\
\hline Urine $\mathrm{Na}^{+}, \mathrm{mEq} / \mathrm{l}$ & $66.9 \pm 27.9$ & $71.6 \pm 23.5$ & $\mathrm{NS}$ \\
$\mathrm{Urine}^{+}, \mathrm{mEq} / \mathrm{l}$ & $31.8 \pm 14.0$ & $23.7 \pm 12.1$ & $<0.05$ \\
$\mathrm{Urine}^{-}, \mathrm{mEq} / \mathrm{l}$ & $55.8 \pm 22.4$ & $64.5 \pm 23.0$ & $\mathrm{NS}$ \\
$\mathrm{FE}_{\mathrm{Na}}, \%$ & $1.9 \pm 1.8$ & $4.3 \pm 4.5$ & $<0.01$ \\
$\mathrm{FE}_{\mathrm{K}}, \%$ & $21.9 \pm 16.0$ & $39.8 \pm 35.3$ & $\mathrm{NS}$ \\
$\mathrm{FE}_{\mathrm{Cl}}, \%$ & $2.45 \pm 0.88$ & $2.9 \pm 1.0$ & $\mathrm{NS}$ \\
$\mathrm{FE}_{\mathrm{UA}}, \%$ & $11.0 \pm 9.0$ & $20.1 \pm 10.3$ & $<0.01$ \\
$\mathrm{FE}_{\text {urea }}, \%$ & $33.8 \pm 13.1$ & $54.9 \pm 43.0$ & $<0.05$ \\
$\mathrm{U} / \mathrm{P}_{\mathrm{Cr}}$ & $41.1 \pm 26.6$ & $21.2 \pm 13.8$ & $<0.01$ \\
\hline
\end{tabular}

Data are means \pm SDs. FE $=$ Fractional excretion; NS = not significant.

Table 5. Logistic regression analysis for predictors of responsiveness to saline hydration

\begin{tabular}{|c|c|c|c|c|}
\hline \multirow[t]{2}{*}{ Predictor } & \multicolumn{2}{|l|}{ Univariate analysis } & \multicolumn{2}{|l|}{ Multivariate analysis } \\
\hline & OR & $\mathrm{p}$ value & OR & $\mathrm{p}$ value \\
\hline Serum albumin & $4.016(1.037-15.55)$ & 0.044 & & \\
\hline Urine $\mathrm{K}^{+}$ & $1.052(0.998-1.109)$ & 0.058 & & \\
\hline $\mathrm{U} / \mathrm{P}_{\mathrm{Cr}}$ & $1.050(1.009-1.093)$ & 0.015 & & \\
\hline $\mathrm{FE}_{\mathrm{Na}}$ & $0.755(0.578-0.985)$ & 0.038 & & \\
\hline $\mathrm{FE}_{\mathrm{UA}}$ & $0.911(0.845-0.982)$ & 0.015 & $0.925(0.857-0.998)$ & 0.045 \\
\hline $\mathrm{FE}_{\text {urea }}$ & $0.941(0.893-0.992)$ & 0.024 & & \\
\hline
\end{tabular}

Figures in parentheses represent 95\% CIs.

long-term prognosis of organ function in many progressive renal diseases [10]. Tubulointerstitial damage begins soon after kidney transplantation due to ischemia-reperfusion injury, and resolution of this process is crucial for kidney outcome [11]. The present study suggests that subtle hypovolemia contributes to allograft dysfunction in a subset of long-term KT patients because a brief course of saline hydration induced a small but significant improvement in azotemia in our patients without overt aggravating factors.

Volume depletion is one of the major reversible causes of deteriorating serum creatinine concentrations in KT patients [1]. However, clinical assessment (e.g. physical examination) of dehydration is neither sensitive nor accurate. Although some urinary indices can be indicative of dehydration, there are no data on the appropriate values of urinary indices to allow one to determine what is abnormally low or high in KT patients. Thus, responsive- ness to fluid challenge would be more useful for diagnosing volume depletion.

Our patients responded immediately to fluid challenge, suggesting that they were in a subclinical state of volume depletion. When we classified the patients as responders or nonresponders according to whether or not their azotemia was stabilized for the following month, $70 \%$ of them were found to be responders. It is possible that responsiveness to saline hydration lasts longer in patients with lesser degrees of tubular damage. Thus, we believe that our nonresponders may have suffered from more severe tubular dysfunction than the responders. It is notable that the use of diuretics was not significantly associated with the responsiveness to saline hydration in this study.

In agreement with this idea, nonresponders had lower $\mathrm{U} / \mathrm{P}_{\mathrm{Cr}}$ and higher $\mathrm{FE}_{\mathrm{Na}}, \mathrm{FE}_{\mathrm{UA}}$ and $\mathrm{FE}_{\text {urea }}$ values than responders. In contrast, the degree of azotemia at admis- 
sion did not differ in the two groups. It is interesting that tubular dysfunction may be dissociated from a decline in glomerular filtration rate in a subgroup of KT patients.

Many urinary indices indicative of tubular dysfunction have been used for differential diagnosis of acute kidney injury $[12,13]$. For instance, $\mathrm{FE}_{\mathrm{Na}}$ is useful to distinguish prerenal azotemia from acute tubular necrosis [14]. However, few data on the fractional excretion of solutes have been reported from $\mathrm{KT}$ patients, although $\mathrm{FE}_{\mathrm{Na}}$ and $\mathrm{FE}_{\mathrm{urea}}$ values have been evaluated in acute renal allograft rejection [15]. To the best of our knowledge, we report the significance of $\mathrm{FE}_{\mathrm{UA}}$ in $\mathrm{KT}$ patients for the first time.

Many drugs and medical conditions can interfere with the accuracy of $\mathrm{FE}_{\mathrm{Na}}$ [14]. In particular, diuretics inhibit the active transport of $\mathrm{NaCl}$ along the tubule and alter $\mathrm{FE}_{\mathrm{Na}}$. Likewise, drugs or disease entities that inhibit the active transport of urea will alter $\mathrm{FE}_{\text {urea }}$. Cyclosporine, one of the most important immunosuppressants used in KT patients, has been suggested to interfere with the active transport of urea in the kidney [16]. Some of our patients were using diuretics at admission, and most were using cyclosporine. $\mathrm{FE}_{\mathrm{Na}}$ was not significantly affected by the use of diuretics, probably because of associated tubulointerstitial lesions, whereas $\mathrm{FE}_{\mathrm{urea}}$ and $\mathrm{FE}_{\mathrm{UA}}$ were significantly lowered by diuretic use in this study. However, saline responsiveness was not associated with previous diuretic use. We investigated the independent roles of urinary indices, including $\mathrm{FE}_{\mathrm{Na}}, \mathrm{FE}_{\mathrm{urea}}$ and $\mathrm{FE}_{\mathrm{UA}}$, in predicting saline responsiveness.

Although $\mathrm{FE}_{\mathrm{Na}}$ and $\mathrm{FE}_{\text {urea }}$ were significantly different in responders versus nonresponders, neither $\mathrm{FE}_{\mathrm{Na}}$ nor $\mathrm{FE}_{\text {urea }}$ were independently associated with responsive- ness to saline hydration. Instead, responsiveness to saline hydration was independently associated with $\mathrm{FE}_{\mathrm{UA}}$. Uric acid has traditionally been used as a marker of proximal tubule reabsorption of sodium, and $\mathrm{FE}_{\mathrm{UA}}$ decreases during volume contraction and increases during expansion $[17,18]$. Serum uric acid increases by $1.0-1.4 \mathrm{mg} / \mathrm{dl}$ from subjects on a strict low-salt diet (approx. 20-50 mEq/day) to subjects on a high-salt diet (approx. 170-214 mEq/day) [19-23]. This short-term change is induced by altered renal uric acid excretion [21].

Changes in renal hemodynamics influence the tubular handling of uric acid by decreasing the flow rate or the uric acid concentration in the proximal tubular fluid [24]. Urea transport also occurs in the thin descending limb and inner medullary collecting duct as well as the proximal tubule [25]. These physiologic considerations seem to be compatible with our conclusion that measurement of $\mathrm{FE}_{\mathrm{UA}}$ in long-term KT patients may be the most suitable method of predicting whether unexplained progressing azotemia will be stabilized by saline hydration. The combined use of $\mathrm{FE}_{\mathrm{Na}}, \mathrm{FE}_{\mathrm{UA}}$ and $\mathrm{FE}_{\mathrm{urea}}$ may increase the accuracy of assessment of volume status in the differential diagnosis of acute kidney injury [26]. We believe that the use of these urinary indices is an important means of assessing the reversibility of accelerated allograft dysfunction. Clinicians should take seriously subclinical volume depletion in long-term KT patients.

\section{Disclosure Statement}

No conflicts of interest declared.

\section{References}

1 Nankivell BJ, Kuypers DR: Diagnosis and prevention of chronic kidney allograft loss. Lancet 2011;378:1428-1437.

-2 Meier-Kriesche HU, Schold JD, Kaplan B: Long-term renal allograft survival: have we made significant progress or is it time to rethink our analytic and therapeutic strategies? Am J Transplant 2004;4:1289-1295.

- 3 Vadivel N, Tullius SG, Chandraker A: Chronic allograft nephropathy. Semin Nephrol 2007;27:414-429.

-4 Najafian B, Kasiske BL: Chronic allograft nephropathy. Curr Opin Nephrol Hypertens 2008;17:149-155.
5 Racusen LC, Solez K, Colvin RB, Bonsib SM, Castro MC, Cavallo T, Croker BP, Demetris $A J$, Drachenberg $C B$, Fogo AB, Furness $P$, Gaber LW, Gibson IW, Glotz D, Goldberg JC, Grande J, Halloran PF, Hansen HE, Hartley B, Hayry PJ, Hill CM, Hoffman EO, Hunsicker LG, Lindblad AS, Yamaguchi Y: The Banff 97 working classification of renal allograft pathology. Kidney Int 1999;55:713-723.

- 6 Bell-Reuss E, Trevino DL, Gottschalk CW: Effect of renal sympathetic nerve stimulation on proximal water and sodium reabsorption. J Clin Invest 1976;57:1104-1107.

7 Halloran PF, Melk A, Barth C: Rethinking chronic allograft nephropathy: the concept of accelerated senescence. J Am Soc Nephrol 1999;10:167-181.
8 Monaco AP, Burke JF Jr, Ferguson RM, Halloran PF, Kahan BD, Light JA, Matas AJ, Solez K: Current thinking on chronic renal allograft rejection: issues, concerns, and recommendations from a 1997 roundtable discussion. Am J Kidney Dis 1999;33:150-160.

-9 Seron D, Moreso F, Bover J, Condom E, GilVernet S, Cañas C, Fulladosa X, Torras J, Carrera M, Grinyó JM, Alsina J: Early protocol renal allograft biopsies and graft outcome. Kidney Int 1997;51:310-316.

10 Sesso R, Santos AP, Nishida SK, Klag MJ, Carvalhaes JT, Ajzen $\mathrm{H}$, Ramos OL, Pereira AB: Prediction of steroid responsiveness in the idiopathic nephrotic syndrome using urinary retinol-binding protein and beta-2-microglobulin. Ann Intern Med 1992;116:905-909. 
11 Cosio FG, Grande JP, Wadei H, Larson TS, Griffi n MD, Stegall MD: Predicting subsequent decline in kidney allograft function from early surveillance biopsies. Am J Transplant 2005;5:2464-2472.

12 Miller TR, Anderson RJ, Linas SL, Henrich WL, Berns AS, Gabow PA, Schrier RW: Urinary indices in acute renal failure: a prospective study. Ann Intern Med 1978;89:47-50.

13 Kamel SK, Ethier J, Richardson R, Bear RA, Halperin ML: Urine electrolytes and osmolality: when and how to use them. Am J Nephrol 1990;10:89-102.

-14 Diskin CJ, Stokes TJ, Dansby LM, Radcliff L, Carter TB: Toward the optimal clinical use of the fraction excretion of solutes in oliguric azotemia. Ren Fail 2010;32:1245-1254.

$\checkmark 15$ Corey HE, Greifer I, Greenstein SM, Tellis V, Spitzer A: The fractional excretion of urea: a new diagnostic test for acute renal allograft rejection. Pediatr Nephrol 1993;7:268-272.
6 Lim SW, Li C, Sun BK, Han KH, Kim WY, Oh YW, Lee JU, Kador PF, Knepper MA, Sands JM, Kim J, Yang CW: Long-term treatment with cyclosporine decreases aquaporins and urea transporters in the rat kidney. Am J Physiol Renal Physiol 2004;287:F139F151.

17 Weinman EJ, Eknoyan G, Suki WN: The influence of extracellular fluid volume on the tubular reabsorption of uric acid. J Clin Invest 1975;55:283-291.

18 Fushimi K, Shichiri M, Marumo F: Decreased fractional excretion of urate as indicator of prerenal azotemia. Am J Nephrol 1990;10:489-494.

19 Del Río A, Rodríguez-Villamil JL: Metabolic effects of strict salt restriction in essential hypertensive patients. J Intern Med 1993; 233:409-414.

20 Egan BM, Lackland DT: Biochemical and metabolic effects of very-low-salt diets. Am J Med Sci 2000;320:233-239.

-21 Masugi F, Ogihara T, Hashizume K, Hasegawa T, Sakaguchi K, Kumahara Y: Changes in plasma lipids and uric acid with sodium loading and sodium depletion in patients with essential hypertension. J Hum Hypertens 1988;1:293-298.
22 Ruppert M, Diehl J, Kolloch R, Overlack A, Kraft K, Gobel B, Hittel N, Stumpe KO: Short-term dietary sodium restriction increases serum lipids and insulin in salt-sensitive and salt-resistant normotensive adults. Klin Wochenschr 1991;69(suppl 25):51-57.

23 Skrabal F, Aubock J, Hortnagl H: Low sodi$\mathrm{um} /$ high potassium diet for prevention of hypertension: probable mechanisms of action. Lancet 1981;2:895-900.

24 Senekijan HO, Knight TF, Samson F, Weinman EJ: Effect of flow rate and the extracellular fluid volume on proximal urate and water reabsorption. Kidney Int 1980;17:155161.

25 Smith CP: Mammalian urea transporters. Exp Physiol 2009;94:180-185.

26 Jang JS, Kim HS, Lee SY, Lee SH, Kim SJ, Kwon SK, Kim HY: The clinical significance of the fractional excretion of uric acid and urea in the differentiation of acute kidney injury. Korean J Nephrol 2009;28:219-226. 